\section{Evaluation of pulmonary function in patients submitted to reduction mammaplasty}

Dear Sir,

We recently read with interest the paper by $\mathrm{Cu}$ nha MS et al(1) recently published in Rev Col Bras Cir.

The study offers some important conclusions regarding the benefits of breast reduction in patients with macromastia on lung function. This study demonstrated a significant difference $(p<0.05)$ in postoperative TLC and RV pointing to improvement in ventilatory excursion and pulmonary function following breast reduction surgery.

We would like to raise the following points for discussion.

Due to the small study population the possibility of a type 1 statistical error increases, therefore these results should be interpreted with caution.

The above study documented the change in pulmonary function tests (PFTs) as 'pre-operative' and 'postoperative' only. We understood the post-operative PFTs were measured in the early post-operative period, at 3 months and 6 months post-operatively. It would therefore be interesting to determine whether the improvement in PFTs is merely transient (only significant in the early post-operative phase) or maintained (at 3 and 6 months) as this was not specified by the authors. If the improvement is only a transient phenomenon then the case for breast reduction surgery based on improvement of PFTs only is significantly undermined. By demonstrating a maintained improvement however the benefits of reduction mammaplasty would be highlighted.

Another important point is that lung function test can be a "learned skill" with improved scores (2) over time depending on the number of tests patients undergo (in other words the effort can improve over time just by learning the action required), thus the best way to assess lung function is to have a control group who also have macromastia but do not receive any operative intervention, which was lacking in this study. It is therefore difficult to conclude that the outcome of this work has realistically added to the literature one way or the other.

Kind regards,

Miss KE Carney Specialist Registrar in General Surgery, Sunderland Royal Hospital

Mr OC Iwuchkuwu; Consultant Breast and Oncoplastic Surgeon, Sunderland Royal Hospital

\section{REFERENCES}

1. Cunha MS, Santos LL, Viana AA, Bandeira NG, Lima Filho JA, Meneses JVL. Evaluation of pulmonary function in patients submitted to reduction mammaplasty. Rev Col Bras Cir. 2011:38(1):11-4

2. Guidelines for the measurement of respiratory function. Recommendations of the British Thoracic Society and the Association of Respiratory Technicians and Physiologists. Respir Med. 1994;88(3):165-94.

\section{RESPOSTA DA CARTA AO EDITOR}

Salvador, 09 de Março de 2012

Prezado Editor

Revista do CBC

Os trabalhos da Literatura que estudaram o assunto apresentaram $\mathrm{n}$ variando de 10 a 73 . O n do trabalho é de 12 (pacientes que foram aproveitadas diante de todo rigor metodológico) e é possível que com o aumento do n possamos evidenciar um falso positivo. Estamos dando continuidade ao trabalho para obter esta resposta.

O período pós operatório de 3 a 6 meses foi considerado diante da dificuldade de retorno de pacientes após este período em nosso serviço e também para evitar a variação de peso com períodos mais longos, comum em nossas pacientes. Outra medida após seis meses nos responderia se as alterações encontradas são transitórias ou não, em nosso serviço isto não foi possível.

Plast. Reconstr. Surg. 118:1, 2006. Este trabalho foi escrito por Iwuagwu, O.C. Trata-se de um trabalho randomizado que utilizou um grupo controle com desenho semelhante de trabalho. Não foram encontradas diferenças estatísticas nos resultados, negando a possibilidade de aprendizado e melhoria dos resultados dos testes de função pulmonar. Desta forma não concordo que seja um teste que modifique com o aprendizado. Acredito nos dados de Iwuagwu que, salvo erro de grafia na carta ao editor, é um dos autores.

Alertamos que todos os dados obtidos com os testes de função pulmonar são normais (pré e pós operatórios) pois tratam-se de pacientes sadias e sem doenças respiratórias. Os resultados sugerem melhorias dos valores e possíveis benefícios em casos em que a fisiologia pulmonar seja ameaçada. Em situações normais, estes resultados não representam alterações clínicas.

Agradeço muito as considerações dos autores. Espero ter respondido aos questionamentos.

Estou à disposição: cunha.ms@ig.com.br

Atenciosamente,

Marcelo Sacramento Cunha

Professor Livre Docente Cirurgia Plástica

Faculdade de Medicina - UFBA 